\title{
The Impact of Urbanization Expansion on the Geomorphology of the Southern Coastal Sabkhas from Ras Al-Jailiaha to Al-Khiran, South Kuwait
}

\author{
A. K. Al-Dalamah, A. E. Al-Hurban \\ Department of Earth and Environmental Sciences, Faculty of Science, Kuwait University, Safat, Kuwait \\ Email: ameenahkh@gmail.com, q8geo@hotmail.com
}

How to cite this paper: Al-Dalamah, A.K. and Al-Hurban, A.E. (2019) The Impact of Urbanization Expansion on the Geomorphology of the Southern Coastal Sabkhas from Ras Al-Jailiaha to Al-Khiran, South Kuwait. Journal of Geographic Information System, 11, 609-632.

https://doi.org/10.4236/igis.2019.115038

Received: May 2, 2019

Accepted: October 27, 2019

Published: October 30, 2019

Copyright $\odot 2019$ by author(s) and Scientific Research Publishing Inc. This work is licensed under the Creative Commons Attribution International License (CC BY 4.0).

http://creativecommons.org/licenses/by/4.0/

\begin{abstract}
Kuwait is considered one of the desert regions of the Arabian Peninsula, that subjected to geomorphological processes forming the earth's surface features. The anthropogenic activities through urbanization affected the earth geomorphology in the southern coastal sabkhas of Kuwait such as (Al-Jailiaha, Az-Zor and Al-Khiran). This study aims to monitor the geomorphological changes on the southern coastal sabkhas due to the urbanization expansion. Geographic information systems (GIS) and remote sensing (RS) techniques were used to study these changes, determine the areas of the coastal sabkhas in the southern part of Kuwait, following the developments, and identifying land cover in the area and its coastal strip including tourist resorts, sand dunes, and smooth sand sheets. The satellite images used in this study based on the data of Landsat-5 (TM) 1985, and Landsat-5 (TM) 1990, Landsat-7 (ETM+) 2001, visuals Landsat-8 (OLI) 2016 covering the years of $(1985,1990$, 2001, 2016), in order to detect changes in the sabkhas and the extension of urbanization in the region. Digital Maps were made to show how extent the study area was affected by urbanization. Urbanization mostly expanded to the south in the study area on the account of the coastal sabkhas, where the area of the coastal sabkhas in 1985 was about $103.1 \mathrm{~km}^{2}$ and in 1990 it was about $84.1 \mathrm{~km}^{2}$. This led to the shrinking of the sabkhas area and extension of the resort area within the areas of sabkhas and sand dunes, particularly in Al-Khiran coastal area exposing it to the problem of sand drift and sand encroachment, which resulted in changes of the characteristics of the sabkhas, shrinkage of their area, and adverse impacts on their geomorphology.
\end{abstract}

\section{Keywords}

Urbanizatrion, Coastal Sabkha, Geographic Information System, Remote 
Sensing, Geomorphology, Change Detection

\section{Introduction}

The state of Kuwait is located at the NW side of the Arabian Gulf and has an area of about $17,818 \mathrm{~km}^{2}$. Kuwait is an arid region characterized by the presence of the southern coastal sabkhas.

Sabkhas was selected as an indicator for the developmental activities in the area due to two considerations: First, sabkhas represents one of the main landforms along the coastal plain of Kuwait, and constitutes a feasible proportion of the total area of Kuwait. Second; their closeness to the coast, which is the most important location in Kuwait and being the old residentially concentrated regions. Therefore, they are considered satisfactorily convenient for urban expansion, particularly where the neighboring areas to sabkhas have been witnessing significant urban expansion of projects such as road networks and infrastructure.

The study area has been witnessing an urban evolution since 2005. In this study geographic information systems and remote sensing techniques were used being efficient and accurate in measuring the area of the sabkhas, which can help the decision-maker in their plans for future development and expansion in this region. They were applied using satellite images of the area for the years of $(1985,1990,2001$, and 2016) to determine the location of the coastal sabkhas in the southern part of Kuwait between Ras Al-Jailiaha to the Al-Khiran (Figure 1), their development and geomorphological changes during the period from (1985-2016).

This study aims to monitor and detect changes on the geomorphological features in the southern coastal sabkhas from Ras Al-Jailiaha to Al-Khiran, as well as to correlate the effect of urban expansion on sabkhas, and construct a modern digital map of the geographical distribution of the sabkhas in the study area. The study also identified the natural and anthropogenic factors for the formation of the sabkhas and its geomorphological development with a description of their mineral, sedimentological, and water chemical characteristics.

\section{Background on Sabkhas}

\subsection{Definition of Sabkhas}

The term "Sabkha" is originally an Arabic name for saline flats or surfaces, which are based on silt and clay, sand and sand formations and are often covered with saline crusts [1]. It describes a low lying land, close to the level of groundwater or sea level as one of the characteristic geomorphological forms of many arid and semi-arid regions. There are several terms of sabkha like "Palya", which is a synonymous of "Mamlahah" inland sabkha [2], and "Salina" which is the percentage of salts in a playa when high enough for a salt crust to form when the 


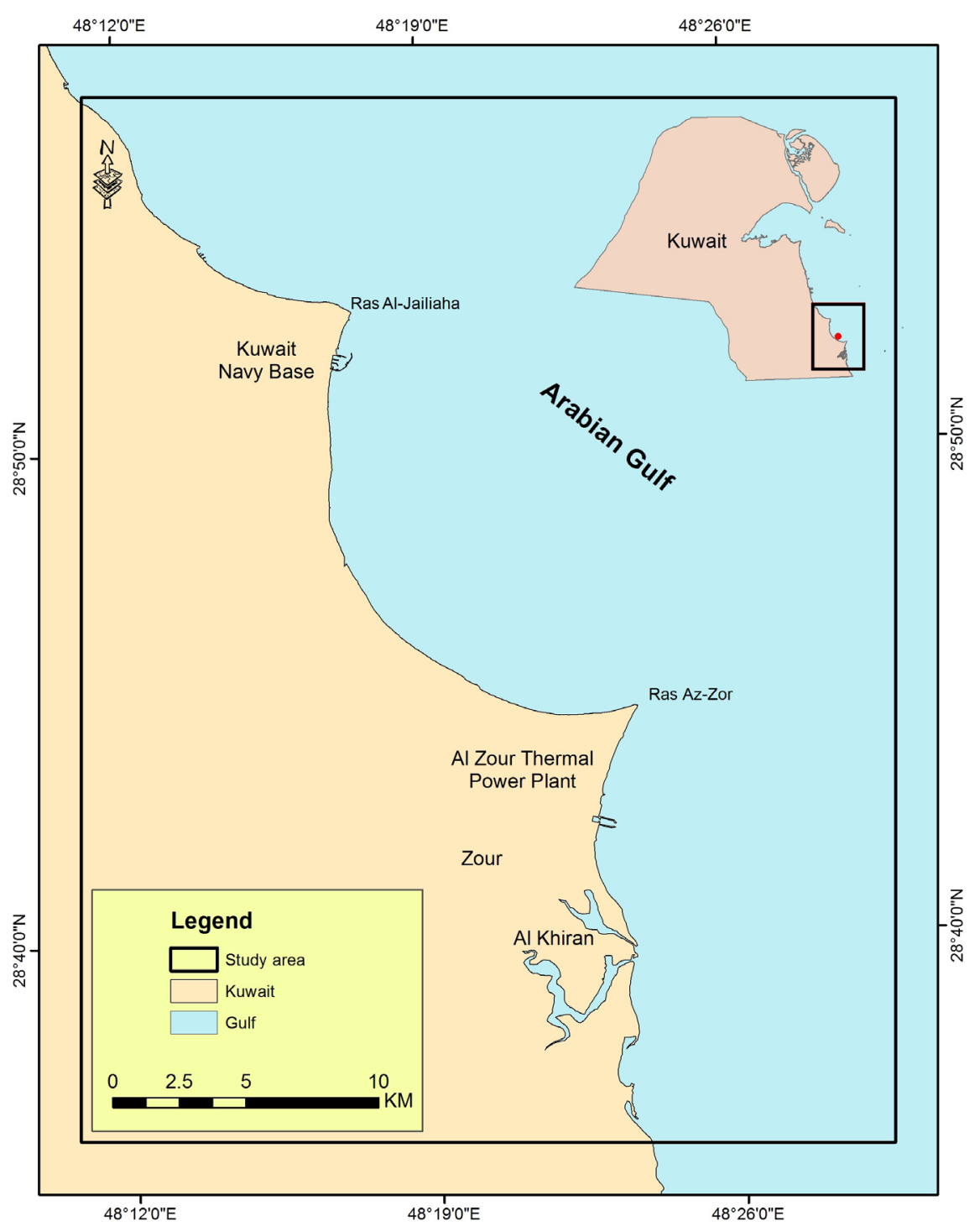

Figure 1. A map showing the study area location using ArcGIS software.

flat is dry in desert areas [3]. Others defined sabkha as a supratidal environment of sedimentation, formed under arid to semiarid conditions on restricted coastal plains just above normal high tide level. Sabkha differs from a salt pan (or an evaporite basin) in that its depositional interface is subaeral, whereas that of a saltpan is subaqueous [4]. Sabkha soils have loose, permeable, sandy to gritty textures. The encrusted surface is composed usually of hygroscopic salts [5].

\subsection{Classification of Sabkhas}

Sabkha landforms have been classified according to different bases: their distance from the sea [6] [7] [8], their sediments' type, their involved sedimentation processes and mode of formation [2] [9], and their mineralogical constituents [10] [11] [12]. Sabkha is found in the scientific literature associated with several prefixes such as coastal, continental, inland and marine, argillam, and eolian. Some refer to the flat salty areas of interior regions as salina [13] [14] [15], or sa- 
line [16]. [17] used the term Playa to describe similar areas of the interior of hot dry deserts. [2], [18] and [19] used sabkha for the coastal features while they called other similar inland features Mamlahah or salina. In this study the term sabkha is used in its original general sense to describe the salt laden flat landforms in coastal regions.

\subsection{Origin of Sabkhas}

The formation of the Arabian Gulf sabkhas is related to the transgression and regression of the Gulf waters from the Late Pleistocene to Holoceneperiods, which witnessed a fluctuation in sea level and deflation processes that form the salt flats and depressions in the area, that later were covered by the deposition of wind-transported sands (Figure 2).

\subsection{Factors Influencing the Sabkha Formation}

According to [4], the factors controlling the formation of sabkhas encompass: 1) Climatic factors, including rainfall that dissolve the precipitated slats within the sabkha strata, during low temperatures and evaporation rate, and diuted the sabkha brine and might raise the water table level [4];2) Temperature, which is the driving force for the evaporation mechanism, where the inland margins of the sabkha have a temperature range from $0^{\circ} \mathrm{C}$ during winter nights to $50^{\circ} \mathrm{C}$ during summer days [20] and the average temperature of the sabkha watertable surface is $34^{\circ}$ [7], while just below the sediment surface of the sabkha, the daily temperature ranges from $18^{\circ} \mathrm{C}$ to $53^{\circ} \mathrm{C}$ [21]; and 3) Winds, which their seasonability and direction play an important role in the genesis of sabkha, as the north to northwest winds Shamal winds, with the accompanying hazy conditions (due to suspended dust), can transport huge quantities of aeolian sands onto and across the sabkha flats [20]. This sand adheres to both damp surfaces and the algal mats and often entire sand dune fields can migrate across sabkhas in offshore conditions, constituting the main reason for producing arenaceous (siliciclastic) sabkhas (deflation basins) [4].

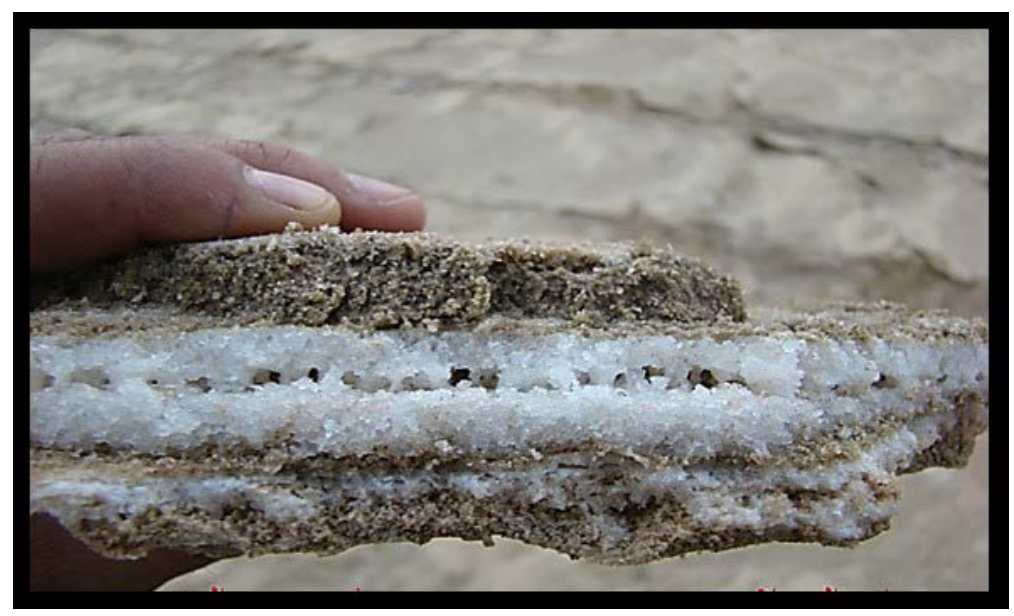

Figure 2. A photograph displaying a zoom on a sabkha sector. 


\subsection{Types of Sabkhas}

Sabkhas are essentially of two types of sabkhas: coastal and inland (continental). Coastal sabkhas are formed as a result of depositional off-lap of marine sediments of subtidal, intertidal and supratidal facies, while inland sabkhas are landward and comprise earlier cycle marine sediments [7]. It is believed that the coastal sabkhas were a large, old-fashioned mullet that was gradually filled with aerosols, in addition to sedimentary and green sediments and carbonate. The anhydrite and salts have been associated with this process of fullness and the underground water field capillary level.

In Kuwait sabkhas are one of the most important characteristic geomorphological phenomena of the coastal and desert plain. They are of two types: coastal sabkhas, as they are close to the coast line and resulted from marine sedimentation processes [22]; and inland sabkhas, as they are far from the coastal line, in the interior, and it is based on the level of groundwater. This study focuses only on coastal sabkhas, particularly in the southern part of Kuwait [23] [24].

Costal sabkha is a wet surface covered by salt flakes distributed along the coast, characterized by a slight slope, and helped the climatic conditions of high temperatures and dryness with the warmth of sea water, the existence of the environment isolated on the formation of deposits of mineral evaporation and local transport [25].

The coastal zone of Kuwait extends from seashore to the highlands, where the coastal deposits are developed, as this area is thought to be submerged and covered with sea water in the earlier ages, evidently by the occurrence of Quaternary oolitic limestone coastal ridges separating the extensive and extremely flat areas (sabkhas) from the open sea. Moreover, the surface of these sabkhas is encrusted by salts, and they are vertically composed of interbedded mud layers with evaporate-rich layers, indicating that they were being occasionally flooded by seawater allowing them to be occupied by algal mats of different structures (Figure 3). Furthermore, the extensive and prolonged intertidal flat sediments are partly originated in ancient projected lagoons to seawater and partly formed in place

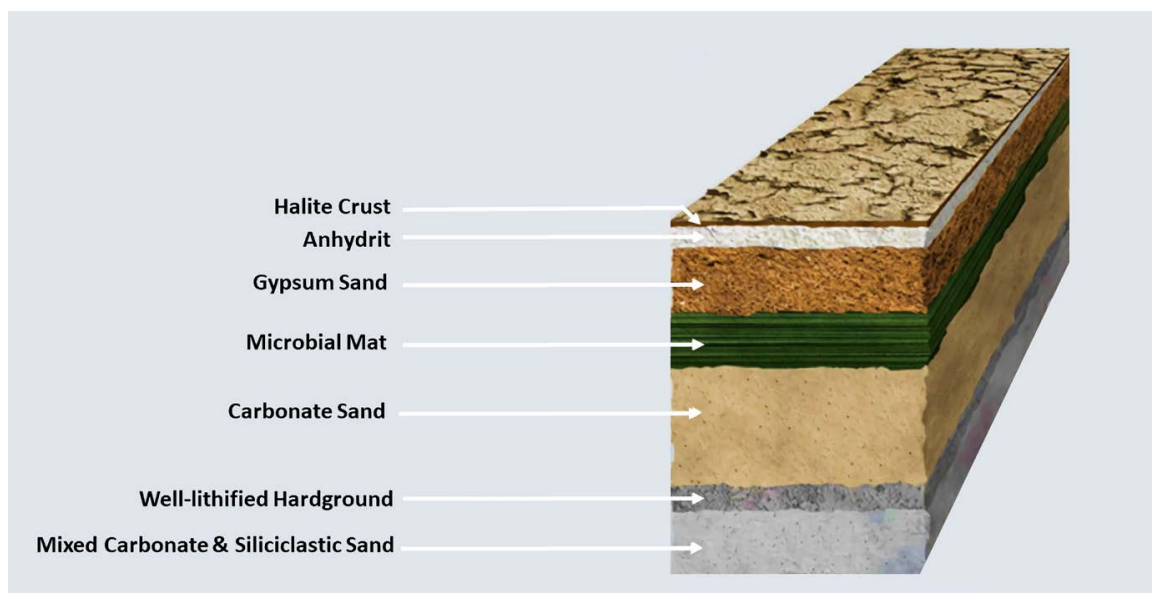

Figure 3. A block diagram showing the coastal sabkha formation. 
by chemical precipitation from water. Coastal sabkhas are affected by coastal morphology, environment, composition of the bed rocks, physical and chemical properties of the sea water, climate and anthropological construction.

The coastal sabkha flats (Figures 4(a)-(c)) occur above normal high tide level in isolated, irregularly shaped patches along the coastal plain. They are mainly flat salt marshes bare of vegetation and covered by evaporate-rich clastic sediments. The sabkhas expand further horizontally, seaward and landside.

The coastal sabkhas growth is affected by several factors including: 1) Tides: evaporation increases the dryness and salinity of sabkha's soil, when the tides move increases the water level on the sabkha's surface and works on the passage of high tide water as well as storm water to the surface of the sabkha in addition

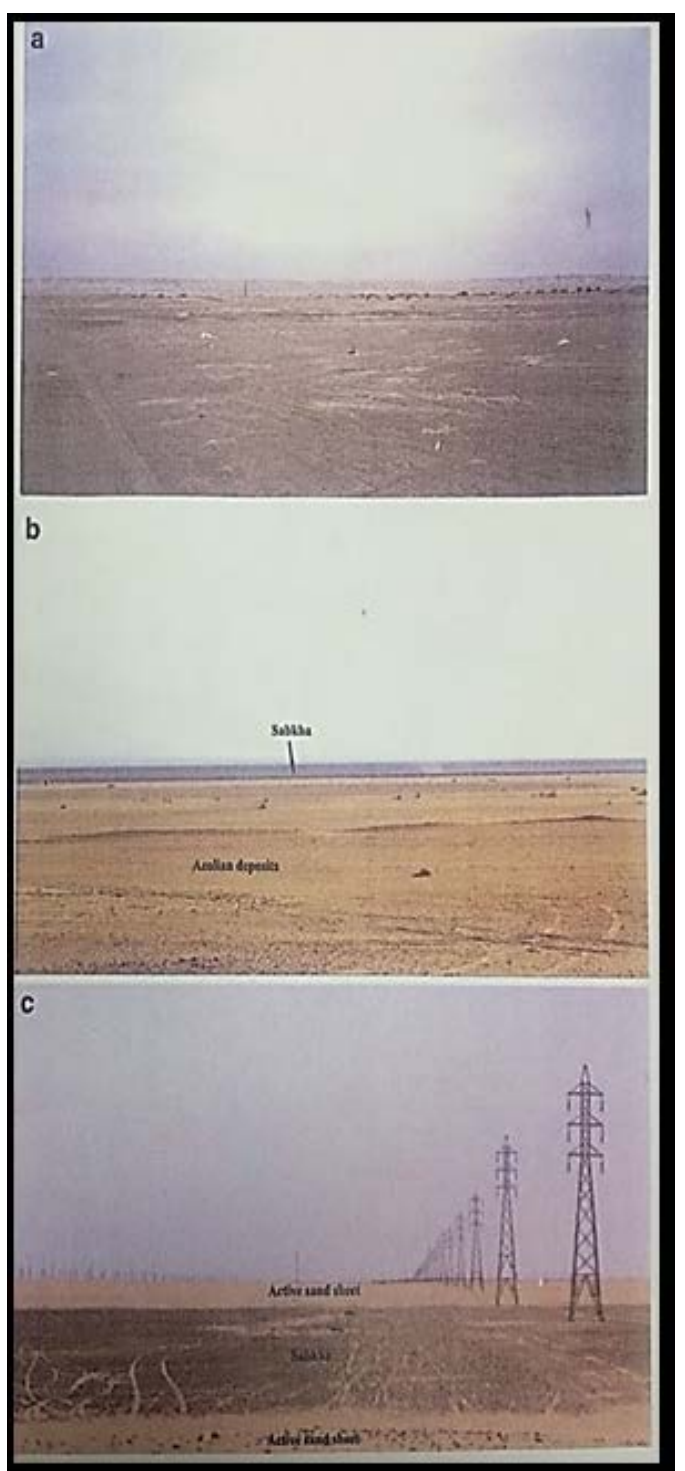

Figure 4. (a-c) field photographs showing coastal sabkha flats in different areas of Kuwait. (a) Coastal sabkha in Al-Khiran area. (b) Coastal plain shows the sabkha covered with Aeolian deposits in Al-Khiran area. (c) Sabkha deposits partially covered by active sand sheet in Al-Khiran area [27]. 
to their sediment rising water in the surface of the sabkha to about 2 meters, especially during periods of storms and thus increases the area of the sabkha that works to rejuvenate again; 2) Sources of sabkha sediments: Sand carried by waves during periods of high tide as well as during periods of storms are the most important sources of sediments for the sabkha as well as the wind from different deposits; and 3) Natural plant: Natural vegetation growing on the surface of the sabkha helps to increase the sediment on the sabkha soil by picking up sediment, which leads to the rise of the bottoms of the sabkha and the elevation of the surface of the surface from the level of times of waterlogging.

Sabkha landforms are characterized by a flat salty non-vegetated terrain associated with a shallow water table which in most cases is found at a depth of less than a meter from the surface. It has been noticed by several authors [8] [26], that the sabkha surfaces represent a state of deflation equilibrium, which means that raising or lowering of the water table in the sabkha system results in accretion or deflation of sediments respectively. During the hot dry Arabian summers, many recent sabkhas became encrusted with salt due to evaporation of moisture brought to the surface by capillary action. Sometimes cracked polygonal structures appear in the surface. During and after rainfall the sabkha surface may be covered by a thin sheet of water.

\subsection{Geographical Distribution of Sabkhas in Kuwait}

Sabkhas constitute one of the most common land-forms along the coastal plain of Kuwait, and it covers about $4.3 \%$ of the total area of the country. It occurs as scattered, irregular, and closed low land areas of different sizes, from Um-Qaser on the Iraqi-Kuwaiti borders in the north, to Al-Nuwaiseeb on the Saudi-Kuwaiti borders in the south (Figure 5 and Figure 6). This study focuses only on coastal sabkhas, particularly in the southern part of Kuwait.

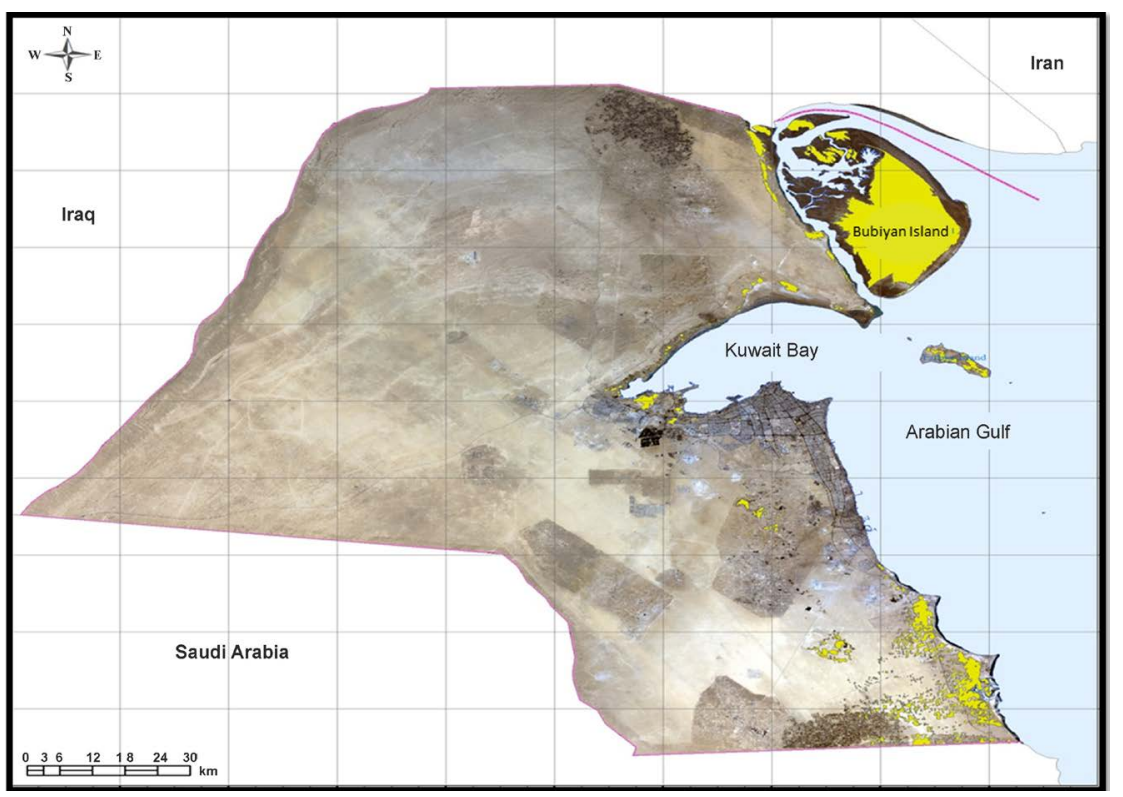

Figure 5. Satellite images show the distribution of Kuwait sabkhas. 


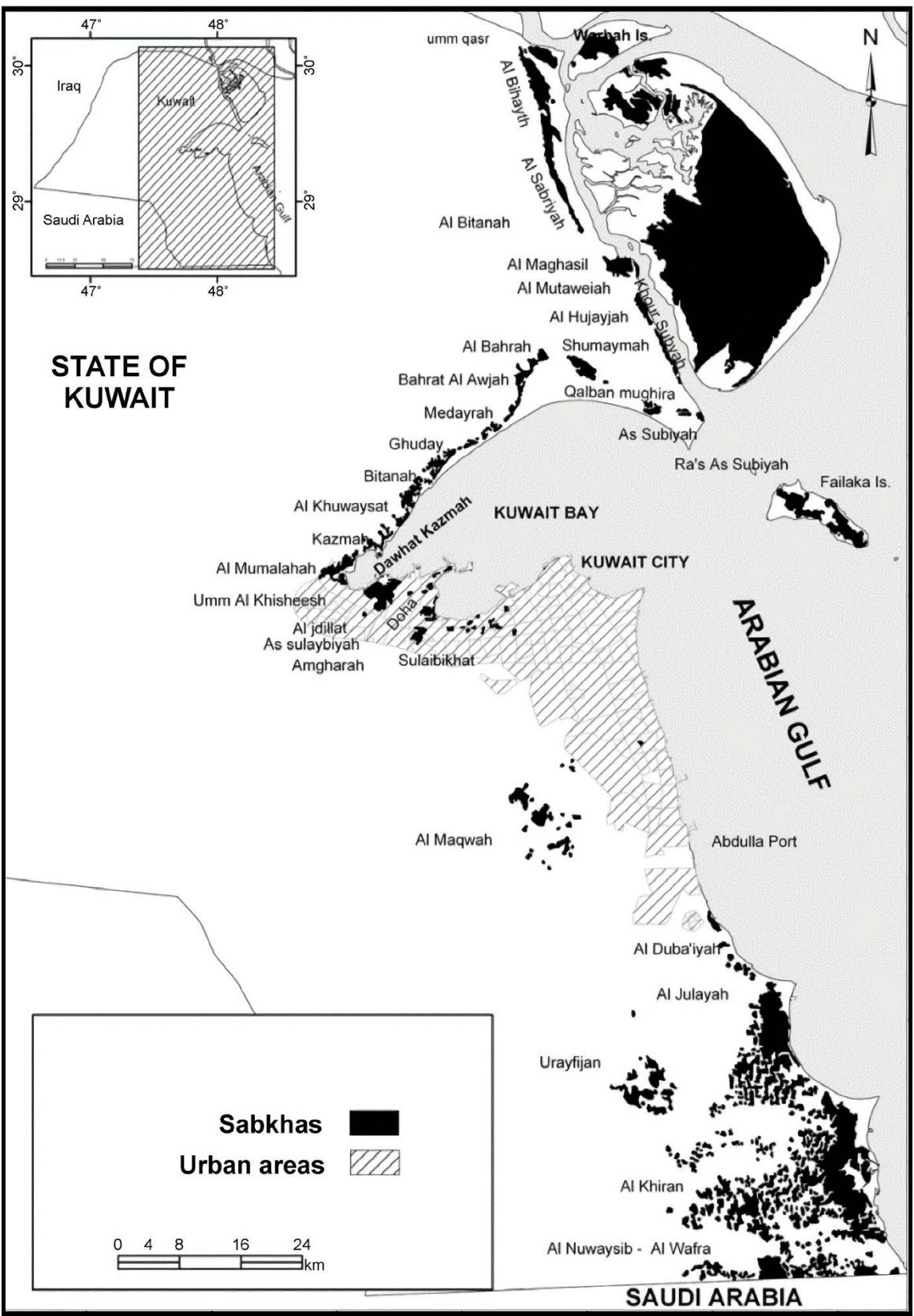

Figure 6. Geographical distribution of sabkhas of Kuwait (Before Human Interference) [23].

\section{Southern Sabkhas}

In southern area, the sabkha was essentially developed to cover a very large area around Al-Khiran tidal creeks. They are separated from the open sea by the $\mathrm{Qu}-$ aternary oolitic limestone coastal ridges extending landward to about $20 \mathrm{~km}$. These sabkhas resemble those of Qatar and Abu Dhabi. Aeolian sand sediments partially cover their inland side. Their deposits are common of brown to light gray in color and loose or slightly consolidated, and their surfaces are encrusted by salts. Interceding's of mud layers and evaporate-rich sand bands were revealed in the sabkha deposits through a vertical section. Sand blown by wind 
from desert in the vicinity played a considerable role in building the stratigraphy within the sabkha deposits.

\subsection{Mineralogical Characteristics of Sabkha Deposits}

Mineralogically, coastal and inland sabkhas are mainly composed of quartz, feldspar, rock fragments, calcareous grains and gypsum (Figure 7). The calcareous grains are mostly represented by skeletal fragments and oolites. The calcareous grains were recorded in the coastal sabkhas and not in inland because of the location of the former closed to the fossiliferous oolitic limestone ridges. Gypsum grains are more common in the coastal sabkha than in inland.

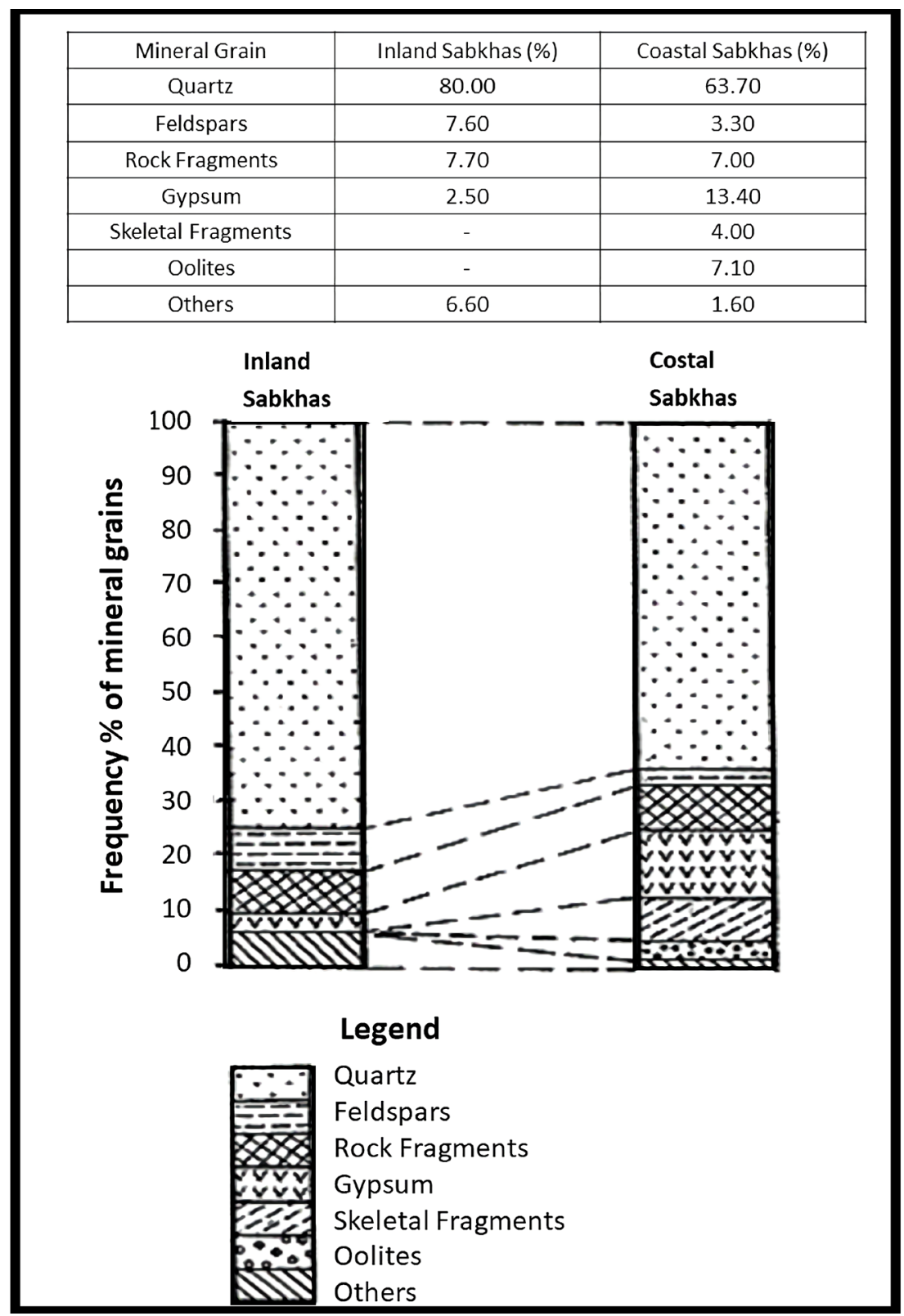

Figure 7. Average relative frequency percentages of the mineral grains in the medium sand size fraction of the coastal and inland sabkha deposits [28]. 


\section{Study Area}

Kuwait is characterized by the presence of the southern coastal sabkhas in Ras Al-Jailiaha, to Al-Khiran areas, where they occupy an area of about $769.4 \mathrm{~km}^{2}$, equivalent to $4.3 \%$ percent of the nation's total area. Their location near the coast, they were a subject of human activities by which they were exploited in urban development. The study area is located between Al-Jailiaha area in the north to Al-Khiran in the south on the coastal line of the State of Kuwait, which is $98 \mathrm{~km}$ away from the capital. It is located between latitude (28.95326 ${ }^{\circ}$ to $28.593536^{\circ} \mathrm{N}$ and between longitude $48.177672^{\circ}$ to $48.501925^{\circ} \mathrm{E}$. The study area is about $1202.3 \mathrm{~km}^{2}$ and mainly geographically distributed in the south of the region (Figure 8). The study area is one of the main cultural and economic components of the country. The importance of the region as a vital tourism investment is part represented in the regions Al-Jailiaha and Al-Khiran, as well as the $\mathrm{Az}$-Zor area, where is considered an industrial zone and oil investments. The urban development took place in the study area during the period from 1985 to 2016 (Figure 1). Urban expansion in the study area along the coastal line from Ras Al-Jailiaha, RasAz-Zor to Al-Khiran area in the south led to the removal and drying of large areas of coastal sabkhas and turning them into urban, tourist and industrial areas and water-filled coves, which led to significant changes in the region's geomorphology.

\section{Methodology}

\subsection{Data Sources}

This study is based on a variety of sources of data such as satellite images and topographic maps of the study area (Figure 9). Four satellite images were obtained from USGS website and included satellite images in 1985 and 1990 with a spatial resolution of $30 \mathrm{~m}$ from the satellite Landsat (TM), satellite images in 2001 with a spatial resolution of $15 \mathrm{~m}$ from the satellite Landsat (ETM+), satellite

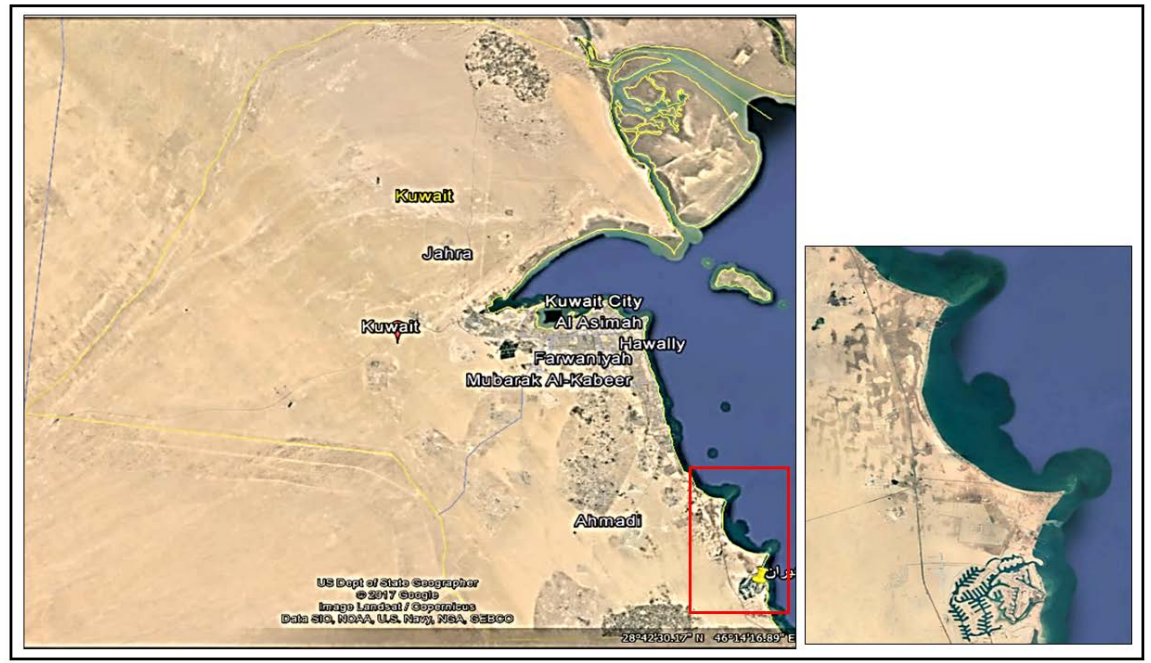

Figure 8. A satellite image showing the study area. 


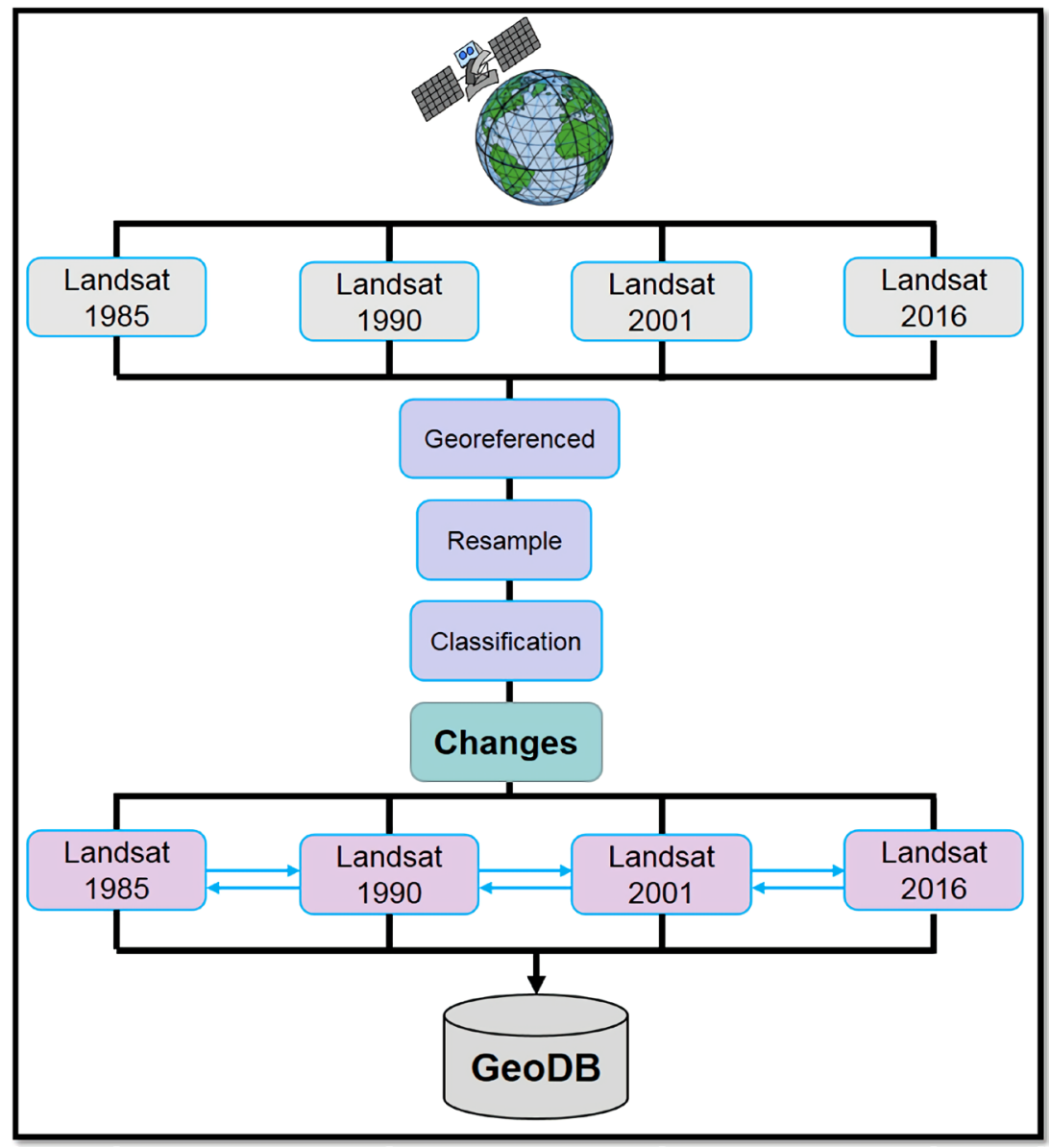

Figure 9. Geodatabase to the study sources.

images in 2016 with a spatial resolution of $15 \mathrm{~m}$ from satellite Landsat-8 (OLI), and high-resolution satellite images from Google Earth in 2016. The topographic maps used were of the State of Kuwait Scale 1:25,000 from the Municipality of Kuwait.

\subsection{Data Analysis Techniques}

Remote sensing and geographic information systems techniques were used to produce maps of the study area showing trends of urban expansion and the development of the sabkha areas of the region during the period from 1985 to 2016 (Figure 10), as well as the creation of maps for sabkhas locations and their directional distribution, and illustrate the changes that have taken place on it. Sabkha location maps were produced and urban expansion changes was calculated in the region by using the ERDAS, ENVI, IMAGINE and ArcGIS softwares.

\section{Satellite Images Analysis}

Processing of the satellite images to obtain required data and information involved the following:

\section{1) Geometric Correction}



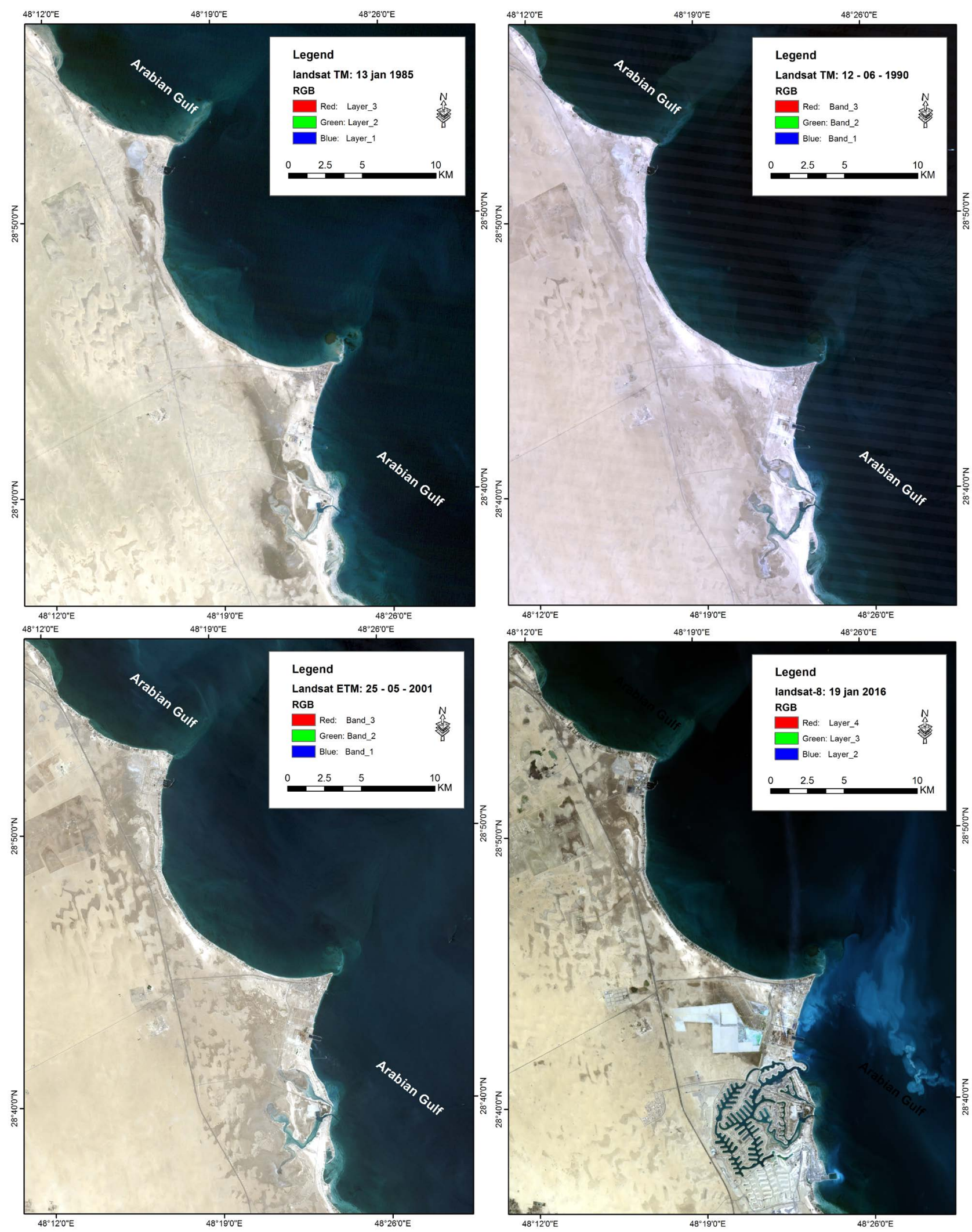

Figure 10. Maps of the study area showing trends of urban expansion and the development of the sabkha areas of the region during the period from 1985 to 1990; Maps of the study area showing trends of urban expansion and the development of the sabkha areas of the region during the period from 2001 to 2016. 
In this study, the geometric correction method (Image to Image registration) is used to register one image to another or an image to a map projection such as the satellite image of 2016, where the image has been geometrically adjusted and matched to all images, using the UTM Zone $39 \mathrm{~N}$. This method was used to detect sabkhas changes in the region.

\section{2) Resampling}

Because of the correction process that may disrupt the pixel size of the image, some of them are increased and others are decreased than what is assumed, so the resampling is done to standardize pixel size and return them to their original size. Resampling method has been used for all images in this study to remove the offset between pixels by (Nearest Neighbor), as they preserve the shape of linear features and pixel value. Nearest neighbor assignment does not change any of the values of cells from the input layer; for this reason, it is often used to resample categorical or integer data (for example, land use, soil, or forest type), or radiometric values, such as those from remotely sensed images.

\section{3) Subset the study area}

The study area is located in the southern coastal area of Kuwait on track No. $40 / 165$, where it was subset (cut) from all satellite images using the angles coordinates of the area between the two latitudes $\left(28.955326^{\circ}\right.$ and $\left.28.593536^{\circ}\right) \mathrm{N}$ and between longitudes $\left(48.177672^{\circ}\right.$ and $\left.48.501925^{\circ}\right) \mathrm{E}$. This process resulted in images of the study area for several periods $(1985,1990,2001,2016)$ using the same coordinates.

\section{4) Enhancement}

After image correction and subset of the study area, image enhancement (improved) was done in Linear Stretch to increase visual differences and to distinguish between different features so that the features look real.

\section{5) Classification}

The implementation of the classification method by sorting each element in the satellite image according to the spectral reflection, then giving each element a single spectral signature in the classification area and different from the others of the elements. This process resulted in the Thematic Map that describes the geographical locations and Earth's surface components characteristics of the study area (land use maps). In this study, images of the study area (Figure 10) were classified as Unsupervised Classification.

\section{a) Unsupervised classification}

Unsupervised classification is the method used to analyze satellite images. It distinguishes between different elements in one image and is used for comparison and differentiation between the main image elements; depending on the spectral signature of the phenomena in the images of any type, without interference in the selection of the spectral signature, then the results were confirmed; and Principal component analysis (PCA) has also been performed, The sabkhas was also identified in the study area through satellite images of Landsat (MSS), Landsat (TM) for 1985, Landsat (TM) for 1990, Landsat (ETM+) for 2001, and Landsat-8 (OLI) for 2016 (Figure 11). 

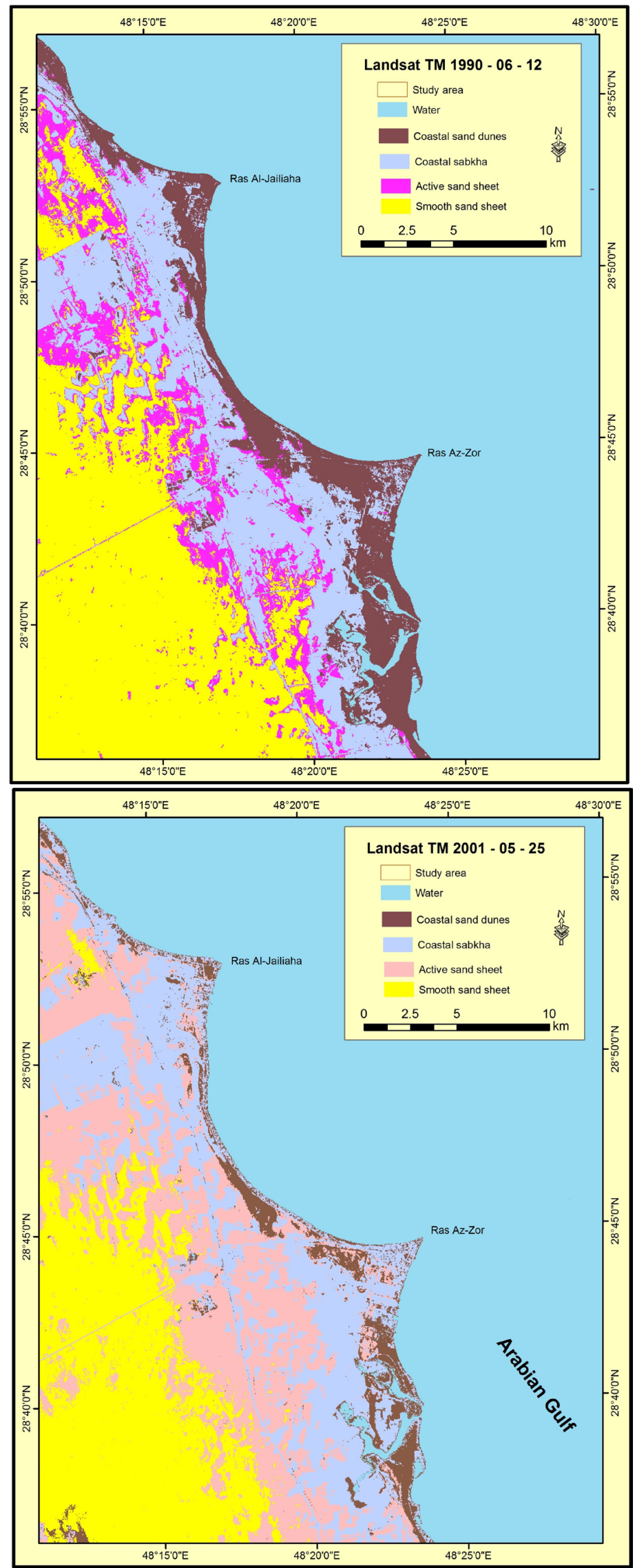


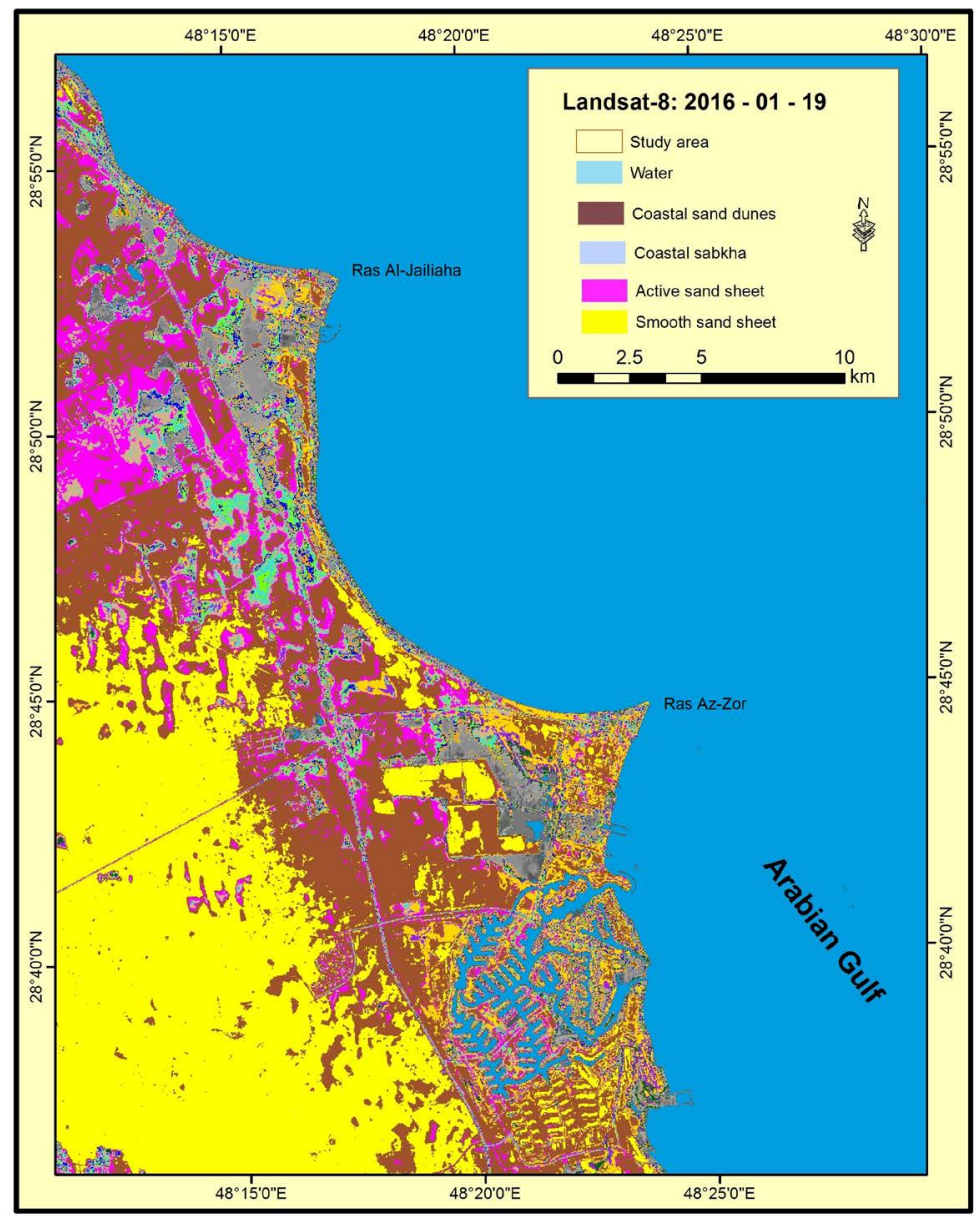

Figure 11. Shows the unsupervised classification for landsat images in the years (1990 and 2001); Shows the unsupervised classification for landsat images in the years (1990 and 2016).

\section{b) Vectorization}

Vectorization method is one of the easiest and most accurate methods. It is used to define areas and convert Raster data into vector data. Thus, it is obtained Polygon, which shows the sabkha areas in the study area, is obtained from the conversion of unsupervised data. This type of vector data helps in the easy account of spaces (areas). This method was applied to all images and digitization was done, including Digitization of Sabkhas.

\section{Results and Discussion}

\section{Change Detection}

The aim of change detection method is to monitor and track the change in the Specific areas of important phenomena by observing the region on satellite images for several years. The methods of change detection are based on observing the differences in the reflection of electromagnetic radiation, which can be observed by monitor the changes in digital numbers, or as often called digital values (Brightness values). 


\section{1) Monitoring the spatial changes of the sabkhas}

Sabkhas in the study area witnessed a significant change in geomorphological characteristics. The distribution of these sabkhas is limited to the coast line of the study area and some small areas in the interior. Sabkha extends longitudinal direction along the Arabian Gulf, punctuated by some urban areas, tourist resorts and industrial zones as illustrated in Table 1.

From Table 1 analysis, it is shown that the area of sabkhas in 1985 was about $103.14 \mathrm{~km}^{2}$, from the images analysis of the American satellite Landsat (TM) (Figure 10), which in 1990 sabkhas area was about $84.13 \mathrm{~km}^{2}$, from the analysis of the satellite images of the US satellite Landsat (TM) There was a $19 \mathrm{~km}^{2}$ decrease in area, increasing the area of sabkhas in the coastal area and the central region of the study area.

An analysis of the spatial locations of the Sabkhas of 2001 showed that the area of $122.1 \mathrm{~km}^{2}$, From the analysis of the Landsat (ETM+) image in 2016, an area of sabkhas amounted about $96.5 \mathrm{~km}^{2}$, this indicates that there are about 25.6 $\mathrm{km}^{2}$ decreased in its area, where the urban area increased, that led to the contraction of the sabkha area.

\section{2) Spatial distribution of the sabkhas}

Analysis and comparison of Landsat for the years 1985-1990 (Figure 12), shows that there is a development in the geographical distribution of the sabkhas scattered in the study area, where the internal sabkhas were found in the area of Al-Wafra in small clusters of scattered areas. Also there are coastal sabkhas that extend along the coast of the region in large continuous ranges Area. Also, the analysis and comparison of Landsat 2001-2016 (Figure 12) show that the area of the coastal sabkhas in Al-Khiran area is reduced due to urban expansion such as tourism development factors and the construction of resorts and chalet.

Analysis and comparison of Landsat images for the period between 1985 and 2016 maps were constructed to show the evolution of the geographical distribution of land cover and the urban expansion in the study area (Figure 13). Some of the changes have occurred in the area of each cover. The area of the spread smooth sand sheet in the region was also decreased due to the urban and agricultural expansion in the Al-Wafra farms. The area of the coastal dunes has also shrunk and replaced by tourist resorts.

3) The relationship between the urban expansion development and its effect on shrinking the area of the sabkhas

Table 1. The change in sabkha areas showing the shrinking of Sabkhas area between (1985-2016)

\begin{tabular}{ccccc}
\hline & Period & Area $\left(\mathrm{Km}^{2}\right)$ & The changes $\left(\mathrm{Km}^{2}\right)$ & Situation \\
\cline { 2 - 5 } Shrinking Sabkha & 1985 & 103.1 & 103 & Constant \\
Areas & 1990 & 84.1 & 19 & Increase \\
& 2001 & 122.1 & -38 & Decrease \\
& 2016 & 96.5 & 25.6 & Increase \\
\hline
\end{tabular}



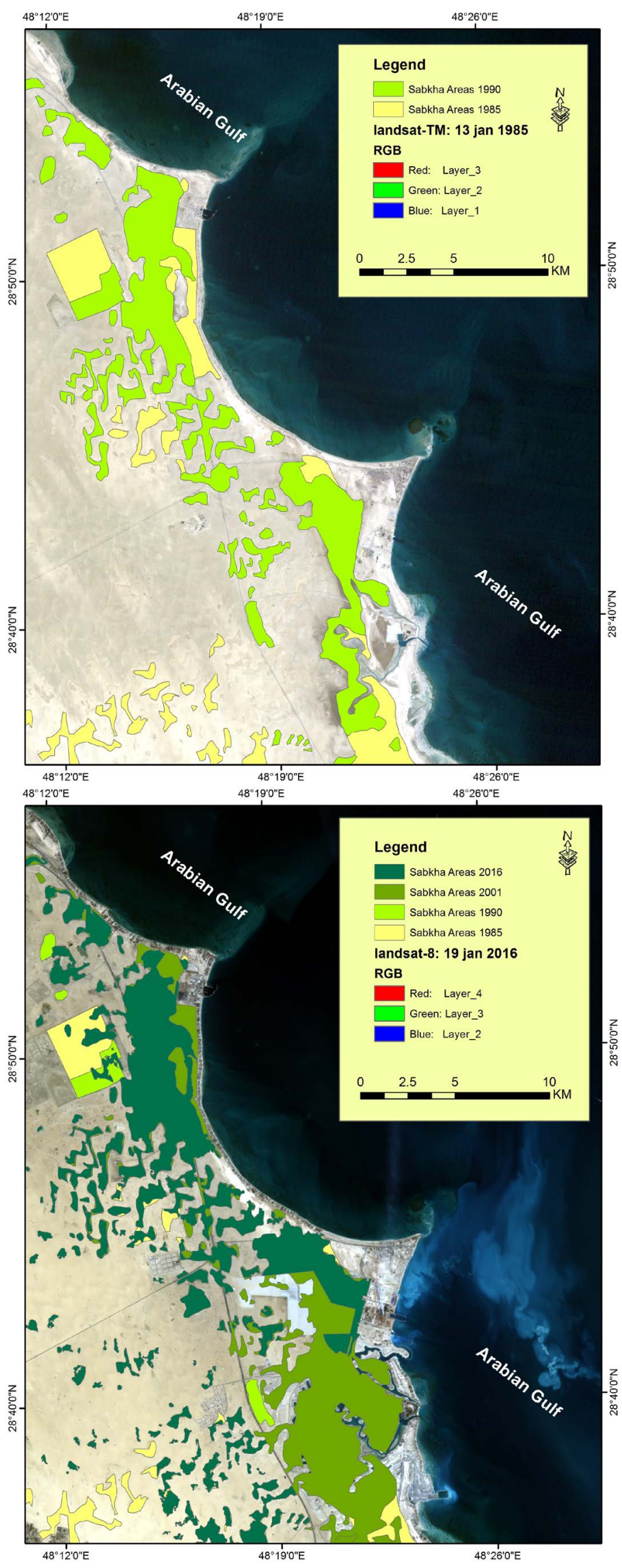


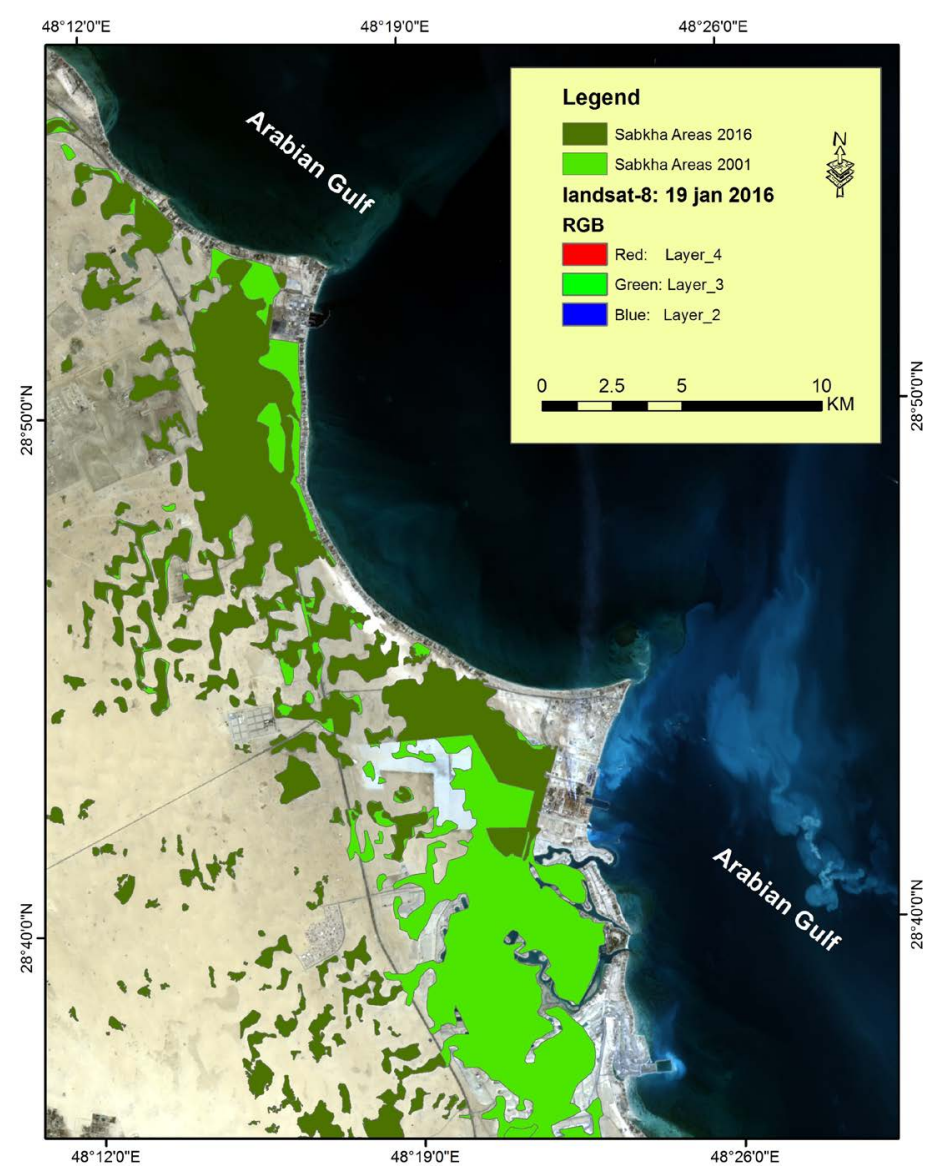

Figure 12. Maps of sabkhas Shrinking during the periods between (1985-1990) and (2001-2016); Maps of sabkhas Shrinking during the periods between (1985-2016).

The analysis of Table 2 shows that the Sabkhas area decreased from 1985 to 2016, And increased in urban areas where the Sabkhas area in 1985 about 103.2 $\mathrm{km}^{2}$, Urban areas about $20.9 \mathrm{~km}^{2}$ has been developed over 31 years at the expense of the area of Sabkhas until the urban areas amounted to $103.9 \mathrm{~km}^{2}$ and the area of Sabkhas about $96.5 \mathrm{~km}^{2}$. This shows the extent of the impact of urbanization in the sabkhas area to shrink in the future or her disappearance.

\section{4) Directional distribution of sabkha}

The analysis and measurement of the geographic distribution (directional distributions) for the sabkhas areas in the study area is based on the differences in the directional distribution from onetime period to another according to the distribution of the sabkhas density. Figure 14 shows that the trend of distribution of sabkha in the study area extending from Ras Al-Jailiah to Al-Zour in 2016 takes the western direction and distanced from the coast. This indicates the contraction of southern coastal sabkhas in Kuwait due to the surrounding anthropogenic activities (landfill and sedimentation). An example is the establishment of a new airport near the new city of Al-Khiran which will help in the development of the region and linking the country to the neighboring countries, as well as, it could be used for sky diving (Figure 15). 

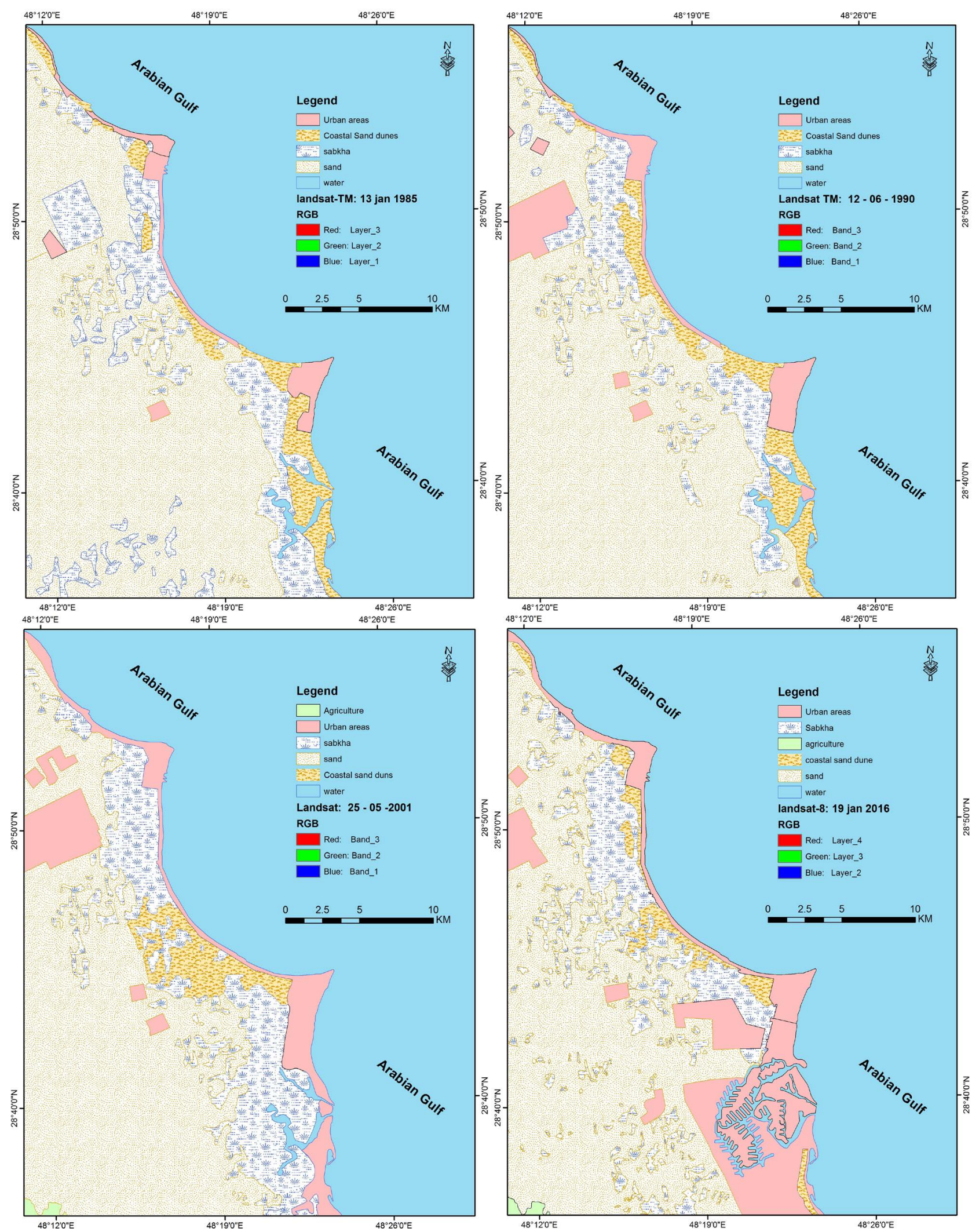

Figure 13. Maps showing the evolution of the geographical distribution of the land cover and urban expansion in the study area during the period (1985-1990); Maps showing the evolution of the geographical distribution of the land cover and urban expansion in the study area during the period (2001-2016). 
Table 2. Development of the land cover in the study area.

\begin{tabular}{cccccc}
\hline \multirow{2}{*}{ Period } & \multicolumn{5}{c}{ Area of land cover $\left(\mathrm{Km}^{2}\right)$} \\
\cline { 2 - 6 } & Sabkha & Urban area & Coastal sand dunes & Smooth sand sheet & Agriculture \\
\hline 1985 & 103.2 & 20.9 & 34.2 & 353.28 & - \\
1990 & 84.1 & 40.6 & 37.9 & 349.9 & - \\
2001 & 122.1 & 64.6 & 26 & 297.89 & 1.97 \\
2016 & 96.5 & 103.9 & 9.1 & 283.4 & 1.97 \\
\hline
\end{tabular}

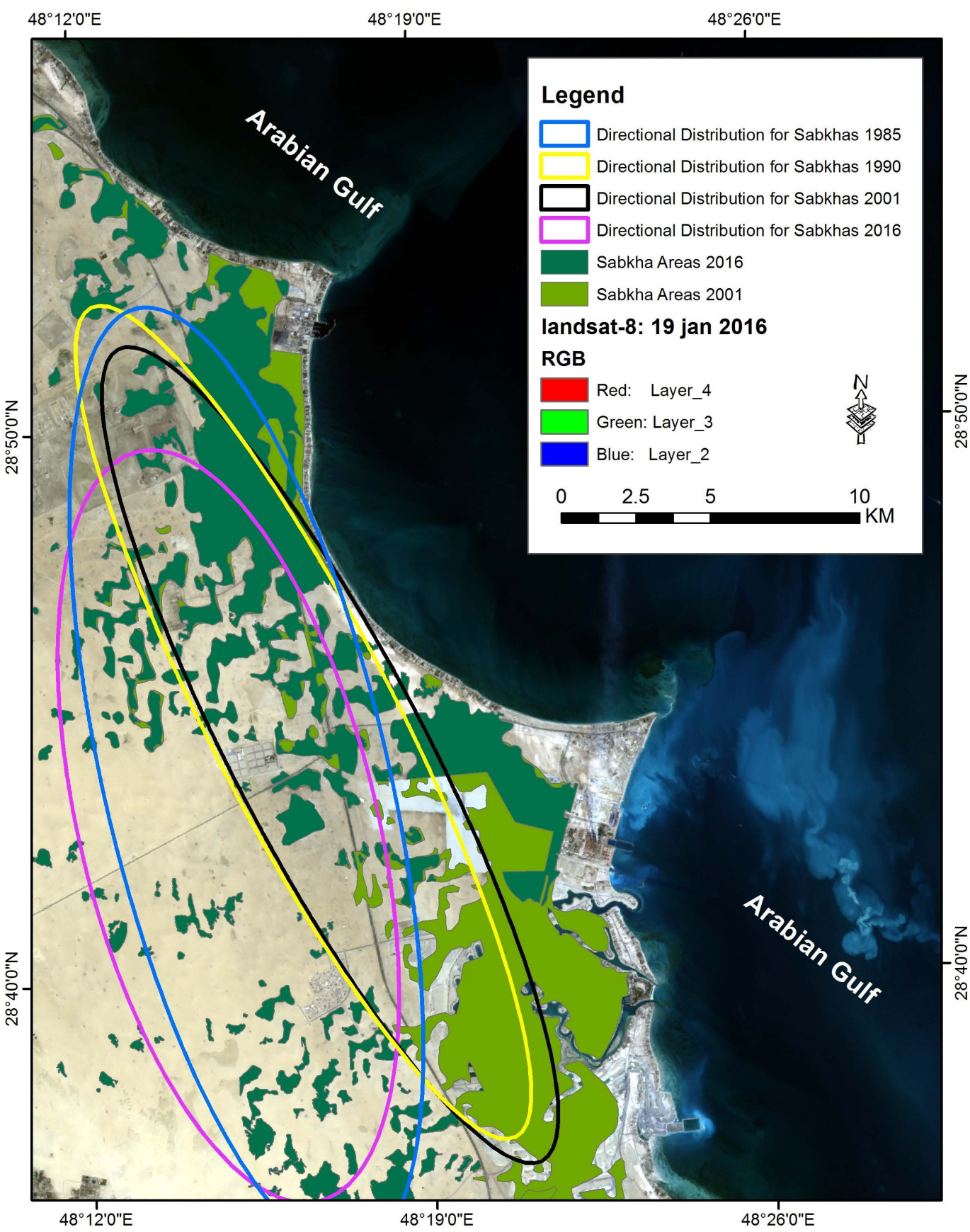

Figure 14. A landsat image shows the change in directional distributions for the sabkhas in the study area. 


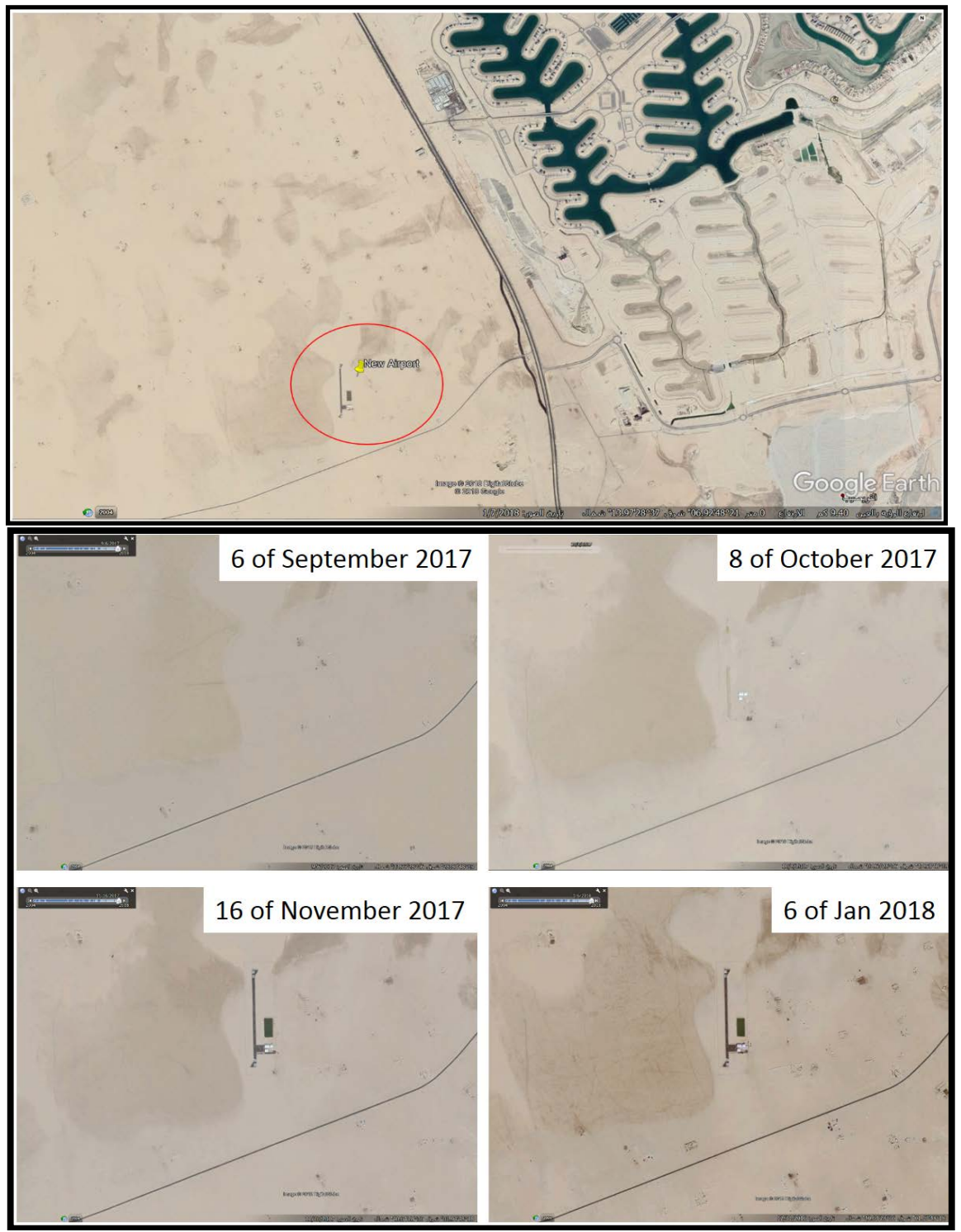

Figure 15. The impact of urbanization expansion on sabkhas example (New Al-Khiran Airport).

\section{Conclusion}

Multi-dated satellite images showed that implementation of the rapid urban expansion had led to significant changes and devastation of important geomorphological features such as the main natural features especially the salt marsh or as locally known as coastal sabkhas, as well as the coastal ridges in the southern sector of Kuwait in the area extending from RasAz-Zor to Al-Khiran area. The vegetation of the sabkhas consists of salinity-tolerant plants which usually grow on the edges around sabkhas and the high parts, where they form the Nabkhas when trapping sand behind them and their roots absorb water. The coastal sabkhas in the study area is characterized by being wet basins parallel to the coastline that extends from the head of Al-Julaiah to Nuweisib area and the Saudi border, and they are flooded or submerged by the high tidal waters, which 
constitutes the main cause for the high salinity of the sabkhas, in addition to the role of nabkhas in trapping the seawater and allowing the leakage of water before reaching the sabkhas. The sabkhas appears as flat lands consisting of homogenous clay deposits with medium to soft sand and evaporites such as gypsum and anhydrite, and calcite originated forms the dissolution of the limestone rocks in and around the study area. The coastal sabkhas has been reduced and the accompanying vegetation cover of salinity-tolerant plants is deteriorated due to the urban expansion and coastal development projects like construction of new cities in the area such as Al-Khiran new city and Sabah Al-Ahmad Sea City. It is worth mentioning that the sabkhas areas are considered unsuitable for urban construction, due to their fragile saline soil, but only after rehabilitation like refilling their land by sand and compacting it, the thing would change the properties and of the existing soil, as well as the natural habitats for the existing species. The moisture of the sabkhas affects the concrete bases of the constructed building and contributes to their erosion. The coastal sabkhas has recorded the highest type of land cover to be affected by these anthropogenic activities, as their area is significantly reduced and the accompanying vegetation cover of salinity-tolerant plants is deteriorated due to this expansion and coastal development projects. The study illustrated that the geomorphic features likely to be affected in the future are the residual coastal sabkhas and the chalets infrastructure due to the urban expansion unless proper precautionary measures are taken.

\section{Acknowledgements}

Authors are grateful to Prof. Mhammed Al-Sarawi and Mrs. Nehaya Saied from the Earth and Environmental Sciences Department, Faculty of Science, Kuwait University, and to Dr. Mohammed Al-Mattar from Geography (Remote Sensing) Department, Faculty of Art, Kuwait University, for their support and suggestions.

\section{Conflicts of Interest}

The authors declare no conflicts of interest regarding the publication of this paper.

\section{References}

[1] Abu Taleb, G.M. and Egeli, I. (1981) Some Geotechnical Problems in the Eastern Province of Saudi Arabia. In: Proceedings of the Symposium on Geotechnical Problems in Saudi Arabia, Vol. 2, King Saud University, Riyadh, 799-811.

[2] Holm, D.A. (1960) Desert Geomorphology in the Arabian Peninsula. Science, 132, 1369-1379. https://doi.org/10.1126/science.132.3437.1369

[3] Von Engeln, O.D. (1942) Geomorphology: Systematic and Regional. The Macmillan Company, New York, 24.

[4] Al-Amoudi, O.S.B., Abduljauwad, S.N., El-Naggar, Z.R. and Rasheeduzzafar (1992) Response of Sabkha to Laboratory Tests-A Case Study. Engineering Geology, 33, 111-125. https://doi.org/10.1016/0013-7952(92)90003-H 
[5] Abduljawad, S.N., Bayomi, F., Al-Sheikh, A.K. and Al-Amoudi, O.S.B. (1994) Influnce of Geotextiles on Performance of Saline Sabkhas Soils. ASCE Journal of Geotechincal Engineering, 120, 1939-1959. https://doi.org/10.1061/(ASCE)0733-9410(1994)120:11(1939)

[6] Sherman, D.J. (1966) Origin of Marine Evaporites by Diagenesis. Transactions of the Institution of Mining and Metallurgy, 75, B208-B215.

[7] Kinsman, D. and Park, R. (1969) Studies of Recent Sedimentology and Early Diagenesis, Trucial Coast, Arabian Gulf. 2 nd Reg. Tech. Symp. Soc. Ptr. Eng. of AIME, Saudi Arabian Section.

[8] Patterson, R.J. (1972) Hydrology and Carbonate Diagenesis of a Coastal Sabkha in the Persian Gulf. PhD Thesis, Princeton University, Princeton, 473.

[9] Purser, B.H. (1985) Coastal Evaporite Systems. In: Friedman, G.M. and Krumbein, W.E., Eds., Ecological Studies 53, Hypersaline Ecosystems, Springer-Verlag, Berlin, 72-102. https://doi.org/10.1007/978-3-642-70290-7 7

[10] Gavish, E. (1974) Geochemistry and Mineralogy of a Recent Sabkha along the Coast of Sinai, Gulf of Suez. Sedimentology, 21, 339-372.

https://doi.org/10.1111/j.1365-3091.1974.tb02067.x

[11] Levy, Y. (1977), The Origin and Evolution of Brine in Coastal Sabkhas, Northern Sinai. Journal of Sedimentary Petrology, 47, 451-462. https://doi.org/10.1306/212F719E-2B24-11D7-8648000102C1865D

[12] Warren, J.K. (1989) Evaporite Sedimentology. Prentice-Hall, Englewood Cliffs.

[13] Warren, J.K. and Kendall, G.C.St.C. (1985) Comparison of Marine Sabkhas (Sub-Aerial) and Salina (Subaqueous) Evaporites: Modern and Ancient. American Association of Petroleum Geologists Bulletin, 69, 1013-1023. https://doi.org/10.1306/AD462B46-16F7-11D7-8645000102C1865D

[14] Aharon, P., Yehoshua, K. and Eytan, S. (1977) Recent Hot Brine Dolomitization in the "Solar Lake," Gulf of Elat, Isotopici, Chemical, and Mineralogical Study. The Journal of Geology, 85, 27-48. https://doi.org/10.1086/628267

[15] Pethuisot, J.P., Floridia, S. and Jauzein, A. (1972) Un Model recent de basin cotier a sedimentation saline: La sebkha el Melah (Zorzis, Tunisie). Revue \& Geologiedynamique et de Geographiephysique, 53, 824-829.

[16] Glennie, K.W. (1970) Desert Sedimentary Environments. In: Development in Sedimentology, Vol. 14, Elsevier, Amsterdam, 57-73 and 121-136.

[17] Goudie, A.S. and Pye, K. (1983) Chemical Sediments and Geomorphology. Academic Press, Cambridge, 490 p.

[18] Powers, R.W., Ramirez, L.F., Redmond, C.D. and Elberg, E.L. (1966) Geology of Arabian Peninsula, Sedimentary Geology of Saudi Arabia. https://doi.org/10.3133/pp560D

[19] Fookes, P.G., French, W.J. and Rice, S.M. (1985) The Influence of Ground and Groundwater Geochemistry on Construction in the Middle East. Quarterly Journal of Engineering Geology, London, 18, 101-128. https://doi.org/10.1144/GSL.QJEG.1985.018.02.01

[20] Purser, B.H. and Seibold, E. (1973) The Principal Environment Factors Influencing Holocene Sedimentation and Diagenesis in the Persian Gulf. In: Purser, B.H., Ed., The Persian Gulf. Holocene Carbonate Sedimentation and Diagenesis in a Shallow Epicontinental Sea, Spriger-Verlag, Berlin, 1-10. https://doi.org/10.1007/978-3-642-65545-6 1

[21] Butler, G.P. (1969) Modern Evaporite Deposition and Geochemistry of Coexisting 
Brines, the Sabkha, Trucial Coast, Arabian Gulf. In: Kirkland, D.W. and Evans, R., Eds., Marine Evaporites: Origin, Diagenesis, and Geochemistry, Dowden, Hutchinson \& Ross, Inc., Stroudsburg, 91-103. https://doi.org/10.1306/74D71BE5-2B21-11D7-8648000102C1865D

[22] Johnson, M.E. (1987) Extent and Bathymetry of North American Platform Seas in the Early Silurian. Paleocenography, 2, 185-211.

https://doi.org/10.1029/PA002i002p00185

[23] Kleo, A. and Al-Otibi, O. (2011) The Sustainable Development of Kuwaiti Sabkha. Digest of Middle East Studies, 20, 27-49. https://doi.org/10.1111/j.1949-3606.2011.00064.x

[24] Al-Hurban, A. (2004) Sabkha. In: Encyclopedia of Geomorphology, Routledge Taylor \& Francis Group, Abingdon-on-Thames, 1156.

[25] Viles, H. and Spencer, T. (1995) Coastal Problems: Geomorphology, Ecology, and Society at the Coast. Wiley, New York, $350 \mathrm{p}$.

[26] Patterson, R.J. and Kinsman, D.J.J. (1981) Hydrologic Framework of a Sabkha along Arabian Gulf. A.A.P.G. Bulletin, 65, 1457-1475. https://doi.org/10.1306/03B5956C-16D1-11D7-8645000102C1865D

[27] Al-Hurban, A. and El-Gamily, H. (2013) Geo-Historical and Geomorphological Evaluation of the Sabkhas and Ridges at Al-Khiran Area, State of Kuwait. Journal of Arid Environmental, 5, 208-221. https://doi.org/10.4236/jgis.2013.53020

[28] Al-Hurban, A. and Gharib, I. (2004) Geomorphological and Sedimentlogical Characteristics of Coastal and Island Sabkha, Southern Kuwait. Journal of Arid Environment, 58, 59-85. https://doi.org/10.1016/S0140-1963(03)00128-9 